DOI: https://doi.org/10.24127/ajpm.v9i3.2747

\title{
PENGEMBANGAN LEMBAR KERJA PESERTA DIDIK BERBASIS PROBLEM BASED LEARNING DALAM MENINGKATKAN KEMAMPUAN REPRESENTASI MATEMATIS SISWA
}

\author{
Qorri Ayuni $^{1}$, Sri Hastuti Noer ${ }^{2}$, Undang Rosidin ${ }^{3}$ \\ ${ }^{1,2}$ Pascasarjana Pendidikan Matematika, Universitas Lampung, Indonesia \\ ${ }^{3}$ Pascasarjana Pendidikan Fisika, Universitas Lampung, Indonesia

E-mail: $\frac{\frac{\text { ayuniqorri@gmail.com }}{\text { l) }}^{\text {hastuti_noer@yahoo.com }}{ }^{2)}}{\text { undangrosidin@ gmail.com }^{3)}}$

Received 09 April 2020; Received in revised form 10 September 2020; Accepted 17 September 2020

\begin{abstract}
Abstrak
Penelitian ini merupakan penelitian pengembangan yang bertujuan untuk menghasilkan produk berupa Lembar Kerja Peserta Didik (LKPD) berbasis problem based learning yang valid dan efektif dalam meningkatkan kemampuan representasi matematis siswa pada materi bentuk aljabar. Tahapan penelitian ini dimulai dari studi pendahuluan, perencanaan, pengembangan produk awal, uji coba lapangan awal, revisi hasil uji coba lapangan awal, dan uji coba lapangan. Subjek penelitian adalah siswa kelas VII SMP Al-Kautsar Bandar Lampung Semester Genap Tahun Pelajaran 2019/2020. Data penelitian ini diperoleh melalui observasi, wawancara, dan tes kemampuan representasi matematis. Hasil penelitian menunjukkan bahwa pertama, desain pengembangan LKPD berbasis problem based learning memiliki kriteria valid. Kedua, rata-rata indeks gain kemampuan representasi matematis siswa yang menggunakan LKPD berbasis problem based learning lebih tinggi dari rata-rata indeks gain kemampuan representasi matematis siswa yang tidak menggunakan LKPD berbasis problem based learning, sehingga LKPD berbasis problem based learning efektif dalam dalam meningkatkan kemampuan representasi matematis siswa.
\end{abstract}

Kata kunci: Kemampuan representasi matematis; LKPD; problem based learning.

\begin{abstract}
This research is a development research that aims to produce a product in the form of student worksheets based on problem based learning that are valid and effective in increasing students mathematical representation skill on algebraic material. The step of this research starts from information collecting, planning, develop preliminary of product, preliminary field testing, revision of the preliminary field testing, and main field testing. This research subjects were students of class VII of SMP Al-Kautsar Bandar Lampung second semester in academic year 2019/2020. Research data obtained through observation, interviews, and test of mathematical representation skill. The results showed that first, the design of the development of the student worksheets based on problem based learning had valid criteria. Second, the average gain index of students mathematical representation skill that used student worksheets based on problem based learning is higher than the average gain index of students mathematical representation skill that didn't use student worksheets based on problem based learning, so that the students' worksheets based on problem based learning are effective in increasing students' mathematical representation skill.
\end{abstract}

Keywords: Mathematical representation skill; problem based learning; student worksheets. 
DOI: https://doi.org/10.24127/ajpm.v9i3.2747

\section{PENDAHULUAN}

Pada kurikulum 2013, fungsi, tujuan, dan karakteristik pembelajaran matematika memerlukan keterampilan siswa dalam mengembangkan kemampuan penalaran, komunikasi, dan pemecahan masalah. Selain itu, diperlukan juga kemampuan dalam menyajikan berbagai bentuk representasi (simbol, persamaan, ataupun gambar) sebagai sarana komunikasi yang baik, singkat, dan jelas dalam menyelesaikan masalah.

$$
\text { Beberapa penelitian yang }
$$

berkaitan dengan problem based learning menunjukkan hasil yang positif terhadap kemampuan representasi matematis siswa, yaitu penelitian yang dilakukan oleh Tandililing (2015) tentang effectivity of Problem Based Learning $(P B L)$ in improving students' mathematical representation; Fitri, Munzir, dan Duskri (2017) tentang meningkatkan kemampuan representasi matematis melalui penerapan model problem based learning; Noer dan Gunowibowo (2018) tentang efektivitas problem based learning ditinjau dari kemampuan berpikir kritis dan representasi matematis; dan Utami, Junaedi, Hidayah, (2018) tentang mathematical representation a bility of students' grade $x$ in mathematics learning on problem based learning. Dari beberapa penelitian tersebut belum ada yang meneliti pengembangan Lembar Kerja Peserta Didik (LKPD) berbasis problem based learning dalam meningkatkan kemampuan representasi matematis siswa.

\section{Kemampuan representasi} matematis adalah kemampuan siswa dalam menginterpretasikan ide-ide matematis terhadap suatu masalah yang digunakan sebagai alat bantu untuk menemukan solusi dari masalah tersebut. Bentuk interpretasi siswa dapat berupa representasi visual (tabel atau gambar), representasi simbolik (persamaan atau simbol matematika) dan representasi verbal (kata-kata atau teks tertulis) (Rangkuti, 2013).

Berdasarkan hasil analisis soal UN matematika SMP dalam bentuk representasi sebanyak 55\%-60\% dari 40 soal atau dengan kata lain lebih dari separuh soal UN matematika tersaji dalam bentuk representasi (Memolo, 2017). Selain itu, hasil analisis oleh Kemendikbud menunjukkan bahwa pada materi aljabar khususnya dalam menyelesaikan soal cerita, presentase siswa yang menjawab soal secara benar sebesar 35,21\%. Hal ini sesuai dengan hasil wawancara kepada siswa SMP AlKautsar Bandar Lampung, yaitu (1) jika dihadapkan dengan soal cerita, beberapa siswa cenderung mengalami kesulitan dalam memahami maksud soal karena terlalu panjang; dan (2) siswa sulit untuk mengubah soal ke dalam bentuk representasi matematis berupa gambar, simbol, maupun persamaan matematika.

Berdasarkan hasil observasi menunjukkan bahwa siswa kurang aktif dan hanya mendengarkan penjelasan guru serta mencatat contoh soal dan penyelesaiannya sehingga mereka sulit untuk memahami konsep dari suatu materi. Dari segi LKPD, lebih banyak berisi rumus-rumus yang disediakan langsung dan latihan-latihan soal. Hal ini mengakibatkan siswa hanya dapat menggunakan rumus tersebut untuk menyelesaikan soal tanpa memahami konsep yang disajikan. Oleh karena itu, diperlukan pengembangan LKPD yang membuat siswa aktif dalam proses pembelajaran. Salah satunya melalui pengembangan LKPD berbasis problem based learning.

LKPD berbasis problem based learning berisi masalah yang harus dipecahkan sehingga siswa terlibat 
langsung dalam penyelesaian masalahnya, aktif dalam menyampaikan ide/ gagasannya, menemukan konsep, serta membuat kesimpulan dan mengevaluasi materi yang dipelajari (Padmavathy \& Mareesh, 2013). Melalui LKPD berbasis problem based learning kemampuan representasi matematis siswa dapat dikembangkan melalui tugas-tugas yang meminta siswa untuk berpikir dan bernalar tentang ide-ide dan konsep matematika. Tugas-tugas tersebut dapat berupa masalah yang berkaitan dengan kehidupan sehari-hari ataupun masalah yang disimulasikan sehingga siswa dapat menemukan sendiri konsep yang mereka pelajari dan membangun pengetahuan baru (Maulana, 2014; Ernawati, 2011).

Pengembangan LKPD berbasis problem based learning ini diharapkan mampu mengatasi permasalahan yang terjadi pada siswa kelas VII di SMP AlKautsar Bandar Lampung, sehingga dapat membuat siswa aktif dan terlibat langsung dalam proses pemecahan masalah yang berdampak postif untuk kemampuan representasi matematis siswa. Oleh karena itu, tujuan penelitian ini adalah menghasilkan LKPD berbasis problem based learning yang valid dan efektif dalam meningkatkan kemampuan representasi matematis siswa pada materi bentuk aljabar.

\section{METODE PENELITIAN}

Penelitian ini adalah penelitian dan pengembangan (Research and Development) dengan tujuan mengembangkan produk berupa LKPD berbasis problem based learning pada materi bentuk aljabar untuk memfasilitasi peningkatan kemampuan representasi matematis siswa di SMP Al-Kautsar Bandar Lampung pada Semester Ganjil Tahun Pelajaran 2019/2020. Adapun tahapan penelitian ini mengacu pada prosedur R\&D dari Borg \& Gall, yaitu:

1. Studi pendahuluan,

2. Perencanaan,

3. Pengembangan produk awal,

4. Uji coba lapangan awal,

5. Revisi hasil uji coba lapangan awal,

6. Uji coba lapangan.

Tahap studi pendahuluan: melakukan observasi dan wawancara kepada guru matematika dan siswa kelas VII terhadap penerapan pembelajaran, bahan ajar, dan kebutuhan LKPD.

Tahap perencanaan yaitu penyusunan perangkat pembelajaran yang terdiri dari LKPD, silabus, RPP, dan instrumen tes kemampuan representasi matematis. LKPD ini di dalamnya berisi tahapan problem based learning, yaitu:

1. Mengorientasi siswa pada masalah,

2. Mengorganisasi siswa untuk belajar,

3. Membimbing penyelidikan individual maupun kelompok,

4. Mengembangkan dan menyajikan hasil karya,

5. Menganalisis dan mengevaluasi proses pemecahan masalah

(Sofyan \& Komariah, 2016).

Selain itu, permasalahan yang terdapat pada LKPD, cara penyelesaian siswa dapat dilihat dari indikator kemampuan representasi matematis sebagai berikut.

1. Representasi visual, yaitu dengan menyajikan kembali informasi dari masalah yang diberikan dengan menggunakan tabel atau gambar.

2. Representasi simbolik, yaitu dengan membuat simbol matematika atau persamaan dari masalah yang diberikan.

3. Representasi verbal, yaitu dengan membuat penjelasan menggunakan kata-kata atau teks tertulis untuk menyelesaikan masalah.

(Rangkuti, 2014). 
DOI: https://doi.org/10.24127/ajpm.v9i3.2747

Tahap pengembangan produk awal: perangkat pembelajaran yang telah disusun pada tahap perencanan, kemudian dilakukan validasi oleh ahli materi dan ahli media serta dilakukan perbaikan sesuai dengan saran para ahli. Instrumen nontes yang digunakan berupa angket validasi untuk mengetahui hasil validasi produk pengembangan tersebut sehingga dapat digunakan pada tahap selanjutnya. Proses validasi dilakukan sampai produk yang dikembangkan memenuhi kriteria minimal untuk dikatakan valid.

Tahap uji coba lapangan awal: dilakukan kepada delapan orang siswa kelas VII yang memiliki kemampuan tinggi, sedang dan rendah. Kedelapan siswa tersebut diberikan instrumen nontes berupa angket yang berisi penilaian, saran, dan masukan terhadap LKPD untuk mengetahui apakah produk tersebut layak digunakan pada tahap selanjutnya. Selain itu, dilakukan juga uji coba instrumen tes berupa soal kemampuan representasi matematis pada kelas VIII I yang terdiri dari 25 orang siswa untuk mengetahui validitas, reliabilitas, tingkat kesukaran, dan daya pembeda soal tersebut.

Tahap revisi hasil uji coba lapangan awal: dilakukan berdasarkan hasil analisis, saran, dan masukan dari angket yang diberikan kepada delapan siswa uji coba.

Tahap uji coba lapangan: dilakukan pada kelas VII D dan VII G SMP Al-Kautsar Bandar Lampung yang masing-masing kelas terdiri dari 30 orang siswa. Kelas VII D sebagai kelas eksperimen menggunakan LKPD berbasis problem based learning, sedangkan kelas VII G sebagai kelas kontrol tidak menggunakan LKPD berbasis problem based learning. Instrumen tes yang digunakan yaitu pretest dan posttest kemampuan representasi matematis siswa.

Teknik pengambilan data dalam penelitian ini, yaitu instrumen nontes dan tes. Instrumen nontes yang digunakan adalah angket menggunakan skala likert dengan empat pilihan jawaban. Angket validasi diberikan kepada ahli materi, ahli media, dan delapan orang siswa untuk menghasilkan produk LKPD berbasis problem based learning yang valid dalam meningkatkan kemampuan representasi matematis siswa. Menurut Khayati (2015) interval nilai validasi angket untuk setiap kategori penilaian ditunjukkan pada Tabel 1.

Tabel 1. Interval nilai validasi angket.

\begin{tabular}{lc}
\hline $\begin{array}{l}\text { Kriteria } \\
\text { Validasi }\end{array}$ & Interval Nilai \\
\hline Sangat & $(\mathrm{S}$ min $+3 \mathrm{p})<\mathrm{S} \leq \mathrm{S}$ maks \\
Baik & $(\mathrm{S}$ min $+2 \mathrm{p})<\mathrm{S}<(\mathrm{S}$ min $+3 \mathrm{p}-1)$ \\
Baik & $(\mathrm{S}$ min $+\mathrm{p})<\mathrm{S}<(\mathrm{S}$ min $+2 \mathrm{p}-1)$ \\
Kurang & $(\mathrm{S}$ min $)<\mathrm{S}<(\mathrm{S}$ min $+\mathrm{p}-1)$ \\
Sangat & \\
Kurang & \\
\hline
\end{tabular}

Selain itu, instrumen tes yang digunakan adalah tes kemampuan representasi matematis. Data dari hasil pretest dan posttest kemampuan representasi matematis siswa dianalisis untuk mengetahui efektivitas produk pengembangan LKPD berbasis problem based learning dalam meningkatkan kemampuan representasi matematis siswa. Menurut Hake (1999) besarnya peningkatan dihitung dengan rumus Gain $(g)$, yaitu:

Gain $(g)=\frac{\text { skor posttest }- \text { skor pretest }}{\text { skor maksimum }- \text { skor pretest }}$

Hasil perhitungan Gain ( $g$ ) kemudian diinterpretasikan dengan menggunakan klasifikasi dari Hake (1999) yang ditunjukkan pada Tabel 2. 
DOI: https://doi.org/10.24127/ajpm.v9i3.2747

Tabel 2. Klasifikasi indeks Gain $(g)$

\begin{tabular}{cc}
\hline Indeks Gain $(\boldsymbol{g})$ & Interpretasi \\
\hline $\mathrm{g}>0,70$ & Tinggi \\
$0,30<\mathrm{g} \leq 0,70$ & Sedang \\
$\mathrm{g} \leq 0,30$ & Rendah \\
\hline
\end{tabular}

\section{HASIL DAN PEMBAHASAN}

Tahap Studi Pendahuluan:

data pada tahap ini diperoleh dari hasil observasi dan wawancara. Observasi dilakukan pada kelas VII dan wawancara dilakukan pada guru matematika yang mengajar di kelas VII. Berdasarkan observasi dan wawancara diperoleh hasil, yaitu: pertama, siswa jarang difasilitasi dengan LKPD. Beberapa materi yang menggunakan LKPD lebih banyak berisi rumus-rumus yang disediakan langsung dan latihanlatihan soal.

Kedua, Pada saat pembelajaran matematika, guru langsung menjelaskan materi dan memberikan contoh soal beserta penyelesaiannya. Selanjutnya siswa diminta untuk mengerjakan soal latihan yang ada dibuku teks atau LKPD. Ketiga, siswa kurang aktif dalam mengajukan pertanyaan atau pemikirannya. Selain itu, siswa raguragu bahkan tidak berani menjawab pertanyaan guru atau menulis jawabannya di papan tulis.

Tahap Perencanaan: dilakukan penyusunan perangkat pembelajaran pada materi bentuk aljabar yang terdiri dari silabus, RPP, LKPD berbasis problem based learning, dan instrumen tes kemampuan representasi matematis. Penyusunan isi LKPD disesuaikan dengan tahap problem based learning.

Tahap Pengembangan Produk

Awal: menghasilkan produk LKPD berbasis problem based learning dalam meningkatkan kemampuan representasi matematis siswa sebagai berikut.

1. Tersaji masalah pada LKPD.
2. Siswa berdiskusi dalam kelompok untuk menyelsaikan masalah.

3. Siswa menyelesaikan masalah secara individu atau kelompok dengan menggunakan tabel atau gambar (representasi visual) dan simbol matematika atau persamaan (representasi simbolik).

4. Siswa mengembangkan dan menulis laporan dengan menggunakan katakata atau teks tertulis dari penyelesaian yang diperoleh kemudian dipresentasikan (representasi verbal).

5. Guru dan siswa menganalisis dan mengevaluasi proses pemecahan masalah, kemudian bersama-sama menyimpulkan materi yang dipelajarinya.

Kemudian produk tersebut divalidasi oleh ahli materi dan ahli media, yaitu Mella Triana, S.Pd., M.Pd. selaku dosen di Universitas Lampung dan Fitria Lestari, S.Pd., M.Pd selaku dosen di Universitas Muhammadiyah Lampung. Selain itu, para ahli memberikan saran dan masukan untuk perbaikan LKPD, yaitu: pertama, perbaiki beberapa kalimat atau kata yang salah pengetikan. Kedua, tambahkan sumber gambar pada setiap LKPD.

Ketiga, lebih diperjelas tentang apa yang dimaksud dengan monomial, binomial, trinomial, dan polinomial. Keempat, tambahkan apersepsi tentang operasi pecahan pada bilangan bulat sehingga siswa dapat lebih mudah memahami operasi pecahan pada bentuk aljabar.

Secara keseluruhan, penilaian terhadap produk pengembangan LKPD oleh para ahli adalah LKPD dapat digunakan dilapangan dengan revisi. Hasil penilaian validasi LKPD oleh ahli materi dan ahli media masing-masing disajikan pada Tabel 3 dan Tabel 4. 
DOI: https://doi.org/10.24127/ajpm.v9i3.2747

Tabel 3. Hasil penilaian validasi LKPD oleh ahli materi.

\begin{tabular}{|c|c|c|c|}
\hline Komponan & $\begin{array}{c}\text { Jumlah } \\
\text { Total }\end{array}$ & $\begin{array}{l}\text { Jumlah } \\
\text { Skor } \\
\text { Ideal } \\
\end{array}$ & $\begin{array}{c}\text { Kategori } \\
\text { Penilaian }\end{array}$ \\
\hline Kelayakan Isi & 61 & 72 & $\begin{array}{c}\text { Sangat } \\
\text { Baik }\end{array}$ \\
\hline $\begin{array}{l}\text { Kelayakan } \\
\text { Penyajian }\end{array}$ & 59 & 72 & $\begin{array}{c}\text { Sangat } \\
\text { Baik }\end{array}$ \\
\hline $\begin{array}{l}\text { Penilaian } \\
\text { Problem Based } \\
\text { Learning }\end{array}$ & 33 & 40 & $\begin{array}{l}\text { Sangat } \\
\text { Baik }\end{array}$ \\
\hline
\end{tabular}

Tabel 4. Hasil penilaian validasi LKPD oleh ahli media .

\begin{tabular}{|c|c|c|c|}
\hline Komponan & $\begin{array}{c}\text { Jumlah } \\
\text { Total }\end{array}$ & $\begin{array}{c}\text { Jumlah } \\
\text { Skor } \\
\text { Ideal }\end{array}$ & $\begin{array}{l}\text { Kategori } \\
\text { Penilaian }\end{array}$ \\
\hline $\begin{array}{l}\text { Kelayakan } \\
\text { Kegrafikan }\end{array}$ & 107 & 128 & $\begin{array}{c}\text { Sangat } \\
\text { Baik }\end{array}$ \\
\hline $\begin{array}{l}\text { Kelayakan } \\
\text { Bahasa }\end{array}$ & 61 & 72 & $\begin{array}{c}\text { Sangat } \\
\text { Baik }\end{array}$ \\
\hline
\end{tabular}

Berdasarkan Tabel 3 dan Tabel 4, diketahui bahwa setiap komponen memiliki kategori penilaian sangat baik. Hal ini berarti LKPD berbasis problem based learning telah valid untuk digunakan pada tahap uji coba lapangan.

Tahap Uji Coba Lapangan Awal: dilakukan uji coba LKPD kepada delapan orang siswa kelas VII. Setiap siswa memberikan penilaian pada angket respon siswa. Hasil penilaian uji coba tersebut disajikan pada Tabel 5.

Tabel 5. Hasil penilaian uji coba LKPD.

\begin{tabular}{lccc}
\hline Komponan & $\begin{array}{c}\text { Jumlah } \\
\text { Total }\end{array}$ & $\begin{array}{c}\text { Jumlah } \\
\text { Skor } \\
\text { Ideal }\end{array}$ & $\begin{array}{c}\text { Kategori } \\
\text { Penilaian }\end{array}$ \\
\hline $\begin{array}{l}\text { Tampilan } \\
\text { LKPD }\end{array}$ & 180 & 224 & Baik \\
$\begin{array}{l}\text { Penyajian } \\
\text { Materi LKPD }\end{array}$ & 213 & 256 & $\begin{array}{c}\text { Sangat } \\
\text { Baik } \\
\text { Manfaat }\end{array}$ \\
$\begin{array}{l}\text { LKPD } \\
\text { Sangat } \\
\text { Baik }\end{array}$ \\
\hline
\end{tabular}

Berdasarkan Tabel 5, diketahui bahwa komponen memiliki kategori penilaian baik dan sangat baik. Hal ini berarti LKPD berbasis problem based learning dapat digunakan di lapangan. Selain uji coba LKPD, dilakukan juga uji coba instrumen tes kemampuan representasi matematis pada kelas VIII I. Hasil uji coba tersebut dianalisis untuk mengetahui validitas, reliabilitas, tingkat kesukaran, dan daya pembeda soal sehingga instrumen tes dapat digunakan di lapangan. Hasil analisis uji coba tersebut disajikan pada Tabel 6.

Tabel 6. Hasil uji coba instrumen tes kemampuan representasi matematis siswa.

\begin{tabular}{cccccc}
\hline No. Soal & Validitas & Reliabilitas & Tingkat Kesukaran & Daya Pembeda & Kesimpulan \\
\hline 1 & 0,82 (Valid) & & 0,57 (Sedang) & 0,42 (Baik) & Dipakai \\
2 & 0,68 (Valid) & 0,75 & 0,67 (Sedang) & 0,44 (Baik) & Dipakai \\
3a & 0,46 (Valid) & (Reliabilitas & 0,59 (Sedang) & 0,42 (Baik) & Dipakai \\
3b & 0,66 (Valid) & Tinggi) & 0,68 (Sedang) & 0,42 (Baik) & Dipakai \\
4 & 0,85 (Valid) & & 0,57 (Sedang) & 0,88 (Sangat Baik) & Dipakai \\
\hline
\end{tabular}

Berdasarkan Tabel 6, diketahui bahwa hasil reliabilitas soal yaitu soal memiliki reliabilitas tinggi dan setiap butir soal memiliki validitas yang valid. Selain itu, untuk tingkat kesukaran butir soal termasuk kategori sedang dan daya pembeda butir soal juga termasuk kategori baik dan sangat baik. Jadi, dapat disimpulkan bahwa butir soal tes kemampuan representasi matematis dapat dipakai pada uji coba lapangan.

Tahap Revisi Hasil Uji Coba Lapangan Awal: dilakukan berdasarkan hasil uji coba serta saran dari delapan orang siswa terpilih. Adapun beberapa bagian yang perlu direvisi, yaitu: pertama, memperjelas langkahlangkah penyelesaian untuk mem- 
permudah siswa dalam memahami cara operasi penjumlahan dan pengurangan bentuk aljabar. Kedua, pengecekan kembali LKPD yang dikembangkan untuk mengetahui apakah terjadi kesalahan dalam pengetikan atau pencetakan.

Tahap Uji Coba Lapangan: dilakukan pada kelas VII D sebagai kelas eksperimen menggunakan LKPD berbasis problem based learning dan VII G sebagai kelas kontrol tidak menggunakan LKPD berbasis problem based learning. Pada penelitian ini guru sebagai fasilitator dan pembimbing siswa dalam mengerjakan LKPD. Pada awal pembelajaran, kelas eksperimen maupun kelas kontrol diberikan pretest untuk mengetahui kemampuan representasi matematis awal siswa. Kemudian di akhir pembelajaran diberikan posttest untuk menguji peningkatan (gain) kemampuan representasi matematis siswa. Selanjutnya, data hasil pretest, posttest, dan gain dianalisis sehingga diperoleh hasil yang disajikan pada Tabel 7.

Tabel 7. Data skor kemampuan representasi matematis siswa

\begin{tabular}{cccccc}
\hline Data & Kelas Penelitian & Banyak Siswa & Rata-Rata & Sig. (2-tailed) & Kesimpulan \\
\hline \multirow{2}{*}{ Pretest } & Eksperimen & 30 & 1,27 & 0,085 & \multirow{2}{*}{ Sig. $>0,05$} \\
& Kontrol & 30 & 0,87 & & \multirow{2}{*}{ Sig. $<0,05$} \\
\multirow{2}{*}{ osttest } & Eksperimen & 30 & 24,20 & 0,014 & \\
\multirow{2}{*}{ Gain } & Kontrol & 30 & 18,43 & & \multirow{2}{*}{ Sig. $<0,05$} \\
& Eksperimen & 30 & 0,59 & 0,014 & \\
\hline
\end{tabular}

Berdasarkan Tabel 7, diketahui bahwa: pertama, data kemampuan awal (pretest) diuji dengan menggunakan Mann-Whitney $U$ dan diperoleh nilai Sig. > 0,05 yang berarti bahwa tidak ada perbedaan kemampuan awal representasi matematis siswa yang menggunakan LKPD berbasis problem based learning dengan kemampuan awal representasi matematis siswa yang tidak menggunakan LKPD berbasis problem based learning.

Kedua, data kemampuan akhir (posttest) diuji dengan menggunakan uji kesamaan dua rata-rata dan diperoleh Sig. $<0,05$ yang berarti bahwa ada perbedaan kemampuan representasi matematis siswa yang menggunakan LKPD berbasis problem based learning dengan yang tidak menggunakan LKPD berbasis problem based learning. Jika dilihat dari rata-rata skor posttest, maka dapat disimpulkan bahwa kemampuan representasi matematis siswa yang menggunakan LKPD berbasis problem based learning lebih tinggi daripada kemampuan representasi matematis siswa yang tidak menggunakan LKPD berbasis problem based learning atau dengan kata lain LKPD berbasis problem based learning efektif untuk meningkatkan kemampuan representasi matematis siswa.

Ketiga, sama halnya dengan data kemampuan akhir (posttest), data gain memiliki nilai Sig. $<0,05$ dan jika dilihat dari rata-rata gain, maka dapat disimpulkan bahwa peningkatan kemampuan representasi matematis siswa yang menggunakan LKPD berbasis problem based learning lebih tinggi daripada peningkatan kemampuan representasi matematis siswa yang tidak menggunakan LKPD berbasis problem based learning. 
DOI: https://doi.org/10.24127/ajpm.v9i3.2747

Keempat, jika berdasarkan interpretasi dari klasifikasi indeks gain, maka gain kemampuan representasi matematis siswa termasuk dalam peningkatan dengan kategori sedang. Meskipun sama-sama mengalami peningkatan dengan kategori sedang, namun peningkatan kemampuan representasi matematis siswa yang menggunakan LKPD berbasis problem based learning memiliki rata-rata indeks gain yang lebih tinggi daripada rata-rata indeks gain kemampuan representasi matematis siswa yang tidak menggunakan LKPD berbasis problem based learning.
Peningkatan kemampuan representasi matematis siswa yang menggunakan LKPD berbasis problem based learning memiliki kemampuan representasi matematis yang lebih baik karena pada pelaksanaan pembelajaran di kelas diawali dengan siswa dibentuk ke dalam beberapa kelompok kemudian dibagikan media pembelajaran berupa LKPD berbasis problem based learning (tahap mengorientasi siswa pada masalah). Produk LKPD berbasis problem based learning disajikan pada Gambar 1.
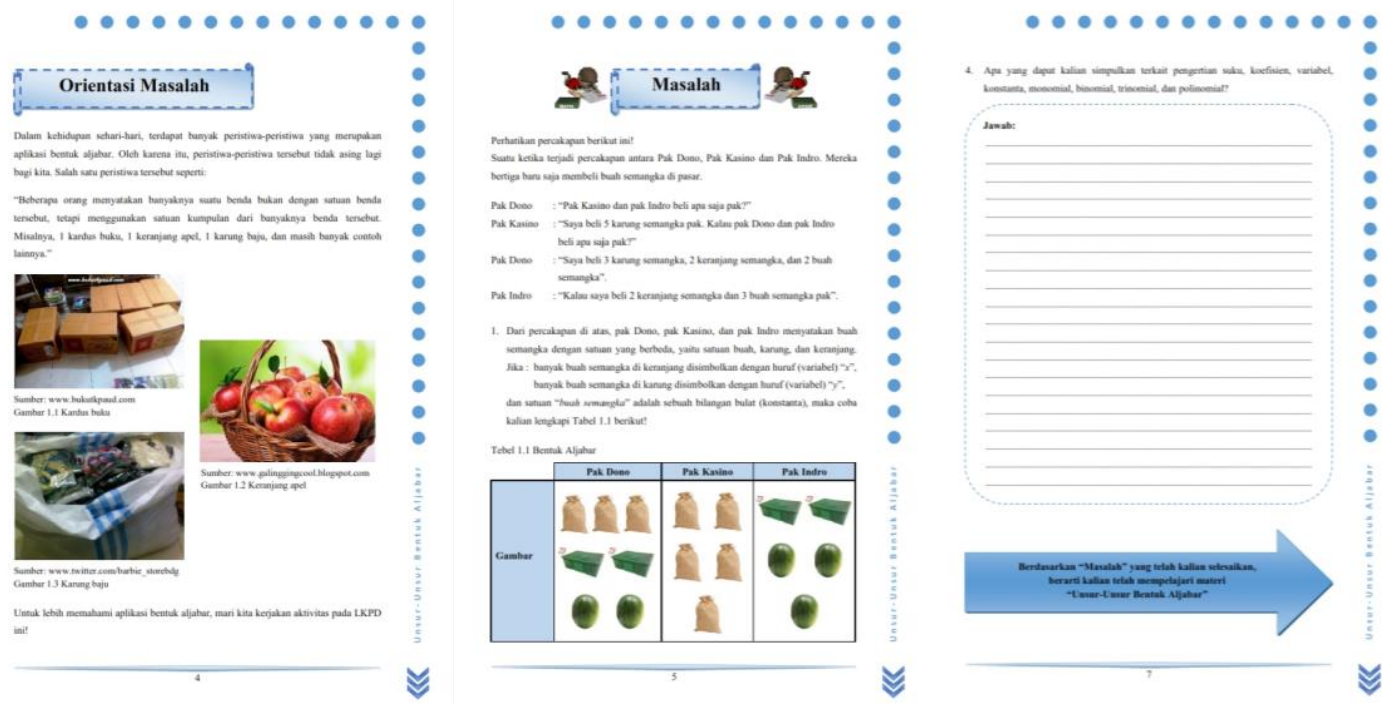

Gambar 1. Produk LKPD berbasis problem based learning.

Berdasarkan Gambar 1, dapat dilihat bahwa pada LKPD berbasis problem based learning tersaji masalah yang membuat siswa tertarik untuk mengolah konsep matematika yang dipelajari. Dalam proses pembelajaran, penggunaan media dapat menarik perhatian siswa, menjadikan pembelajaran lebih interaktif, meningkatkan kualitas hasil belajar, serta menumbuhkan sikap positif siswa terhadap materi dan pembelajaran (Karo-Karo \& Rohani, 2018).
Fachrurazi (2011) dalam penelitiannya mengatakan bahwa fokus problem based learning adalah pada masalah yang diselesaikan sepenuhnya oleh siswa, mulai dari berpikir untuk menemukan solusi dari suatu masalah sampai dengan proses untuk memahami suatu konsep dan prosedur yang terkandung dalam masalah tersebut.

Selanjutnya, siswa membaca LKPD dan mengumpulkan informasi dari berbagai sumber guna menyelesaikan masalahnya (tahap 
DOI: https://doi.org/10.24127/ajpm.v9i3.2747

mengorganisasikan siswa untuk belajar). Kemudian, siswa berdiskusi dengan untuk memecahkan permasalahan yang terdapat pada LKPD (tahap membimbing penyelidikan individual maupun kelompok). Pada tahap ini, guru bertindak sebagai fasilitator serta membimbing ketika siswa mengalami kesulitan. Siswa harus membangun sendiri pengetahuan dan mengembangkan konsep sesuai dengan persepsi yang mereka miliki. Penanaman konsep secara mendalam dapat membuat siswa menggunakan, mengevaluasi dan membuat kesimpulan yang tepat dalam menyelesaikan permasalahan, sehingga pembelajaran matematika lebih bermakna.

Setelah diskusi kelompok, siswa menulis laporan berupa penyelesaian/ jawaban dari permasalahan yang terdapat pada LKPD (tahap mengembangkan dan menyajikan hasil karya). Laporan tersebut disajikan dalam berbagai bentuk representasi seperti tabel atau gambar (representasi visual), simbol matematika atau persamaan (representasi simbolik), dan kata-kata atau teks tertulis (representasi verbal). Hal ini sejalan dengan pendapat Ertikanto, dkk. (2018) yang menyatakan bahwa problem based learning menghasilkan pengetahuan konseptual dengan baik serta menghasilkan kemampuan siswa dalam merepresentasikan suatu masalah dengan baik pula. Selain itu, hasil penelitian Utami, dkk (2018) diperoleh simpulan bahwa pada problem based learning kualitas representasi matematis siswa termasuk dalam kategori baik.

Selanjutnya, beberapa kelompok mempresentasikan hasil diskusi mereka dan kelompok lain menanggapinya. Dari hasil diskusi, guru melakukan evaluasi dan klarifikasi, kemudian guru dan siswa bersama-sama menyimpulkan materi yang dipelajarinya (tahap menganalisis dan mengevaluasi proses pemecahan masalah). Dari kesimpulan tersebut, guru memberikan umpan balik berupa saran dan masukan untuk pembelajaran selanjutnya.

Pengembangan LKPD berbasis problem based learning dapat membuat siswa aktif dan terlibat langsung dalam proses pemecahan masalahnya serta siswa juga akan terbiasa menggunakan kemampuan representasi matematisnya. Selain itu, penelitian ini juga menghasilkan produk berupa LKPD berbasis problem based learning serta perangkat pembelajaran pada materi bentuk aljabar.

Berdasarkan penjelasan di atas, dapat disimpulkan bahwa LKPD berbasis problem based learning efektif yang dihasilkan dapat meningkatkan kemampuan representasi matematis siswa. Hal ini sejalan dengan hasil penelitian Fitri, dkk (2017) bahwa problem based learning mempengaruhi peningkatan kemampuan representasi matematis siswa. Selain itu, hasil penelitian Noer dan Gunowibowo (2018) menyimpulkan bahwa problem based learning efektif ditinjau dari kemampuan represesentasi matematis.

\section{KESIMPULAN DAN SARAN}

Berdasarkan hasil penelitian dan pembahasan, diperoleh simpulan bahwa pertama, pengembangan LKPD berbasis problem based learning valid dan efektif dalam meningkatkan kemampuan representasi matematis siswa pada materi bentuk aljabar. Kedua, Peningkatan kemampuan representasi matematis siswa yang menggunakan LKPD berbasis problem based learning lebih tinggi daripada peningkatan kemampuan representasi matematis siswa yang tidak menggunakan LKPD berbasis problem 
DOI: https://doi.org/10.24127/ajpm.v9i3.2747

based learning dan termasuk dalam peningkatan dengan kategori sedang.

Adapun saran untuk penelitian selanjutnya hendaknya dapat mengembangkan LKPD berbasis problem based learning pada kemampuan matematis yang lain dan melibatkan aspek afektif.

\section{DAFTAR PUSTAKA}

Ernawati, D. (2011). Pengaruh Model Pembelajaran Berbasis Masalah (Problem Based Learning) dan Model Pembelajaran Konvensional Terhadap Prestasi Belajar Akuntansi Ditinjau dari Motivasi Belajar Siswa (Skripsi). Surakarta: Universitas Negeri Sebelas Maret.

Ertikanto, C., Rosidin, U., Distrik, I. W., Yuberti, Y., \& Rahayu, T. (2018). Comparison of Mathematical Representation Skill and Science Learning Result in Classes with ProblemBased and Discovery Learning Model. Jurnal Pendidikan IPA Indonesia, 7(1), 106-113.

Fachrurazi. (2011). Penerapan Pembelajaran Berbasis Masalah untuk Meningkatkan Kemampuan Berpikir Kritis dan Komunikasi Matematis Siswa Sekolah Dasar. Jurnal Penelitian Pendidikan UPI, Edisi Khusus(1), 76-89.

Fitri, N., Munzir, S., \& Duskri, M. (2017). Meningkatkan Kemampuan Representasi Matematis melalui Penerapan Model Problem Based Learning. Jurnal Didaktik Matematika, 4(1), 59-67.
Karo-Karo, I. R. \& Rohani. (2018). Manfaat Media dalam Pembelajaran. Jurnal Axiom, VII(1), 91-96.

Khayati, F. (2015). Pengembangan Model Matematika untuk Pebelajaran Berbasis Masalah (Problem Based Learning) pada Materi Pokok Persamaan Garis Lurus Kelas VIII SMP (Tesis). Surakarta: Universitas Negeri Sebelas Maret.

Maulana, D. (2014). Pendekatan Saintifik (Scientific Approach): Implementasi untuk K-13 (Kurikulum 2013). Bandar Lampung: LPMP Provinsi Lampung.

Memolo, T. (2017). Analisis Ujian Nasional Matematika SMP Tahun 2014 sampai 2017 dalam Tinjauan Representasi. Prosiding Seminar Nasional Pendidikan, Sains dan Teknologi (pp. 391-397). Semarang: Universitas Muhammadiyah Semarang.

Noer, S. H., \& Gunowibowo, P. (2018). Efektivitas Problem Based Learning Ditinjau dari Kemampuan Berpikir Kritis dan Representasi Matematis. Jurnal Penelitian dan Pembelajaran Matematika, 11(2), 17-31.

Padmavathy, R. D., \& Mareesh, K. (2013). Effectiveness of Problem Based Learning in Mathematics. International Multidisciplinary E-Journal, II(I), 45-51.

Rangkuti, A. N. (2013). Representasi Matematis. Logaritma Jurnal Ilmu-Ilmu Pendidikan dan Sains, 1(2), 49-61. 
DOI: https://doi.org/10.24127/ajpm.v9i3.2747

Rangkuti, A. N. (2014). Representasi Matematis. Forum Paedagogik Jurnal Pendidikan Agama Islam, VI(01), 110-127.

Sofyan, H., \& Komariah, K. (2016). Pembelajaran Problem Based Learning dalam Implementasi Kurikulum 2013 di SMK. Jurnal Pendidikan Vokasi, 6(3), 260271.

Tandililing, E. (2015). Effectivity of Problem Based Learning (PBL) in Improving Students' Mathematical Representation. Proceeding of International Conference on Research, Implementation and Education of Mathematics and Sciences (pp. 147-152). Yogyakarta: Universitas Negeri Yogyakarta.
Utami, P. R., Junaedi, I., \& Hidayah, I. (2018). Mathematical Representation Ability of Students' Grade X in Mathematics Learning on Problem Based Learning. Unnes Journal of Mathematics Education, 7(3), 164-171. 